\title{
Being Present in the Administrative Criminal Law: Regulation on Presence of the Hungarian Petty Offence Procedure
}

\author{
ISTVÁN HOFFMAN
}

\begin{abstract}
The petty offences have a dual nature in majority of the European continental legal systems: they are on the crossroads of administrative and criminal law. A similar model evolved in Hungary after the $19^{\text {th }}$ century. The Hungarian regulation on petty offences has moved between administrative and criminal law. Although art 6 of the ECHR is interpreted broadly by the ECtHR, the European Union legislation (the Directive $343 / 2016 / \mathrm{EU}$ ) cannot be applied in the Hungarian petty offence procedures. Despite this narrow approach of the EU legislation, the main guarantees of the Directive are prevailed by the major petty offence cases. If the procedures can result a detention nature punishment (in Hungary: elzárás - custodial arrest) the guarantees of the presence of the defendants mainly prevails. In more administrative - thus minor - cases in Hungary simplified and administrative nature procedural rules are applied. However, the significance of the administrative criminal law is decreasing in Hungary, especially the rise of the 'administratisation' of the liability for minor infringements.
\end{abstract}

Keywords: • petty offence $\bullet$ right to fair trial $\bullet$ presence in criminal cases $\bullet$ Hungary $\bullet$ procedure $\cdot$ dual nature $\bullet$ practice of ECtHR $\bullet$ Directive $343 / 2016 / \mathrm{EU}$

CoRrespondence AdDREss: István Hoffman, Ph.D., Professor, Eötvös Loránd University, Faculty of Law, Department of Administrative Law,H-1053 Budapest, Egyetem tér 1-3, Hungary, email: hoffman.istvan@ajk.elte.hu; Marie Curie-Skłodowska University, Faculty of Law and Administration, Department of International Public Law, Plac Marii Curie-Skłodowskiej 5, 20-031 Lublin, Poland.

https://doi.org/10.4335/978-961-6842-96-9.39-49

ISBN 978-961-6842-96-9 (pdf)

(C) 2020 Institute for Local Self-Government Maribor

Available online at http://www.lex-localis.press. 
I. Hoffman: Being Present in the Administrative Criminal Law: Regulation on Presence of the Hungarian Petty Offence Procedure

The petty offences are crossroads cases between administrative and criminal law, therefore the analysis of the procedural regulation on them can result a comparison of the approaches of the different legal systems and the different legal regulations. Hungary has a continental legal system - which approach survived the age of the Soviet law, as well (Kühn, 2019: 187-188). The Continental - Civil Law - approach was the base of the evolution of the Hungarian regulation, which was influenced strongly by the Soviet Law after 1945. The administrative nature of the Hungarian petty offence law was strengthened by it, thus the had real mixed nature which has been transformed after 2012: the petty offences became the field of administrative criminal law (Nagy, 2012: 218).

The analysis of the relation of the Hungarian petty offence procedures in the light of the presence of the persons subject to proceedings can show the challenges of the European regulation and its limitations. The primary method of the review is jurisprudential, but the social impacts of the regulation will also be partly analysed. Because of the paradigm shift of the Hungarian legislation after 2012, the article will contain a short historical outlook, as well. By this method the challenges on the Hungarian petty (minor) offence system and the answers of the Hungarian legislation could be observed.

\section{Short historical outlook - the beginning of the modern Hungarian criminal and criminal procedure law}

The modern Hungarian criminal and criminal procedure law begun to evolve from the late $18^{\text {th }}$, early $19^{\text {th }}$ century. The National Commissions which were elected by the Parliament in 1791 begun to evolve drafts for the codification of the Hungarian law, especially the criminal and the civil law. Although these drafts were not codified, the codification process continued during the $19^{\text {th }}$ century. One of the most important draft was the draft of 1843/44 on the criminal and on criminal procedure law (Mezey, 1996: 213). Parallel to the codification process a new type of offense have been evolved in the Hungarian legal system, the minor offences (áthágás, kihágás). This new type of offense had just partly criminal nature, because typically they were sanctions for the infringement of the administrative regulations (for example regulations on public health, building inspections, traffic control) (Nagy, 2000: 19). The regulation on the substantive law of the petty offences was codified during the codification of the Hungarian criminal law in the late $19^{\text {th }}$ century. The Hungarian criminal law used a trichotomous system among the criminal acts. The most serious criminal acts were the crimes (büntett). A less serious category was the misdemeanour (vétség). These two types of criminal acts were regulated by the Criminal Code, by the Act V of 1878. The third category of the trichotomy, the petty offences (kihágás) were regulated separately, the substantive law was regulated by the Act XL of 1879 on the Criminal Code for the Petty Offences. Although there was an Act of Parliament on the petty offences, but their administrative nature could be observed by the model of the regulation. Petty offences could be introduced and regulated by 
administrative bodies: by the decree of the ministers and by municipal decrees. The crossroad nature of the regulation could be seen by the procedural rules which were fragmented. The procedural legislation was based on the activities of administrative bodies, because mainly decrees of ministers (and not the Act of Parliament) were passed. A standardisation has taken place in the early $20^{\text {th }}$ century: new, standardised rules were passed in 1909 on the procedure of the police bodies in the field of petty offences (Decree of the Minister of Interior No. 65.000/1909 on the Regulation of Police Criminal Activities). The dual nature of the petty offences remained after the codification: firstly, the Criminal Code on Petty Offences were based on the German Polizei concept, thus the petty offences were partly minor offences, partly infringement of the administrative regulations (Nagy, 2000: 22-23).

After the World War II the Hungarian Criminal law was transformed by the new Soviettype regime. The former trichotomous system was changed and in 1950 a dichotomous model was institutionalised, only crimes and petty offences were regulated. In 1953 a new sanction was introduced, the szabálysértés, which was an administrative act, and its procedure was considered as an administrative one. In 1955 the petty offences as criminal acts were abolished. Although majority of the former petty offences were transformed into the new category, but it was institutionalised as an administrative act, therefore the guarantees of these procedures were merely administrative. In 1968 the legal regulation of the administrative petty offences, the szabálysértés was codified by the Act I of 1968. Although the major rules on them were regulated by an Act of Parliament, majority of the petty offences were regulated by administrative decrees. The szabálysértés became a general form of the administrative sanctions, but the criminal elements and roots remained (Szatmári, 1961: 90). The procedure became more administrative several guarantees of the criminal procedures were regulated by the new Act.

After the fall of Soviet-type regime in Hungary it was necessary to recodify the legal regulations on the petty offences. The Hungarian petty offences are interpreted as criminal case by the European Court of Human Rights (ECtHR). And because of the administrative nature the Act I of 1968 was not consistent to the European Convention on Human Rights (ECHR). Therefore, a reservation was made by the Republic of Hungary during the Hungarian access to the European Convention of Human Rights (ECHR). Therefore the criminal nature of the substantive and the procedural law on petty offences were strengthened by the recodifications of the Hungarian law on petty offences in 1999 (Nagy, 2000: 80) and in 2012 (Nagy, 2012: 220-221).

\section{Between criminal and administrative law: the petty offences in the Hungarian legal system}

As it has been mentioned the petty offences have a dual nature in the current Hungarian legal system. Marianna Nagy summarised this dual nature, that the petty offences - which are regulated by the Act II o 2012 - are administrative criminal acts, those acts which 
have a minor threat to the society. On the other hand, petty offences are partly sanction of the infringements of administrative regulations. These acts can be observed on a 'scale' between these endpoints. As we have mentioned, in the $19^{\text {th }}$ century the criminal nature was more important, but the administrative elements became more important in the mid$20^{\text {th }}$ century. The 'administratisation' tendencies of the petty offence law ended in the 1990s, when stronger, merely criminal procedural guarantees were required by the practice of the ECtHR. The Act on Petty Offences of 1999 has a 'criminalisation' tendency, but the new Act on Petty Offences of 2012 transformed the system. In 2012 the concept of 'administrative criminal law' has been revived (Kis, 2018: 40-45). This dual nature has challenges - like a Scylla and Charybdis. The first question is, whether the punitive power of the administration can be accepted by a system based on the separation of powers and the rule of law. Because the administrative procedures are mainly faster. But one of the main reasons of the faster administrative procedure is the lack of guarantees. And these acts can be interpreted as criminal cases, and the guarantees of the fundamental rights of the defendants are important in a legal regulation based on the concept of rule of law. Therefore, a compromise shall be found when both objectives can be fulfilled (Kis, 2018: 110-118).

The practice of the ECtHR is one of the major guidelines for the guarantees which are required by a legal system based on the rule of law and on the fundamental rights. The relevant regulation of the ECHR is the article on fair trial in civil and criminal cases, the art 6 (1) of the ECHR. The first question is whether this article can be or cannot be applied for the petty offence cases, because the fair trial in criminal cases are regulated by it. The answer is that a broad interpretation of the criminal cases has been evolved by the practice of the ECtHR. The landmark case of that interpretation was the case Engel and others $v$. The Netherlands (Application No. 5100/71; 5101/71; 5102/71; 5354/72 and 5370/72). The Engel case was on a military disciplinary procedure, but this procedure was interpreted by the ECtHR as a 'criminal charge'. In this case a test was created by the ECtHR to determine whether the given case can be or cannot be interpreted as a criminal case (criminal charge). The test has three elements. Firstly, it shall be examined the classification of the proceedings under national law. But this examination is not enough to determine the nature of the proceedings, therefore secondly the essential nature of the offence shall be analysed. And thirdly, the nature and degree of severity of the penalty that could be imposed having regard in particular to any loss of liberty, as a characteristic of criminal liability - shall be analysed (White \& Ovey 2010: 244). Therefore the the 'criminal charge' is interpreted broadly by the ECtHR. In the case Pákozdi v. Hungary (51269/07 an infringement of the art. 6 (1) was stated by the ECtHR. The case Pákozdi was about a judicial review procedure of a tax fine. A first instance court ruling - which avoided imposing a tax fine - has been reversed by a judgement of the Supreme Court. This judgement was delivered without trial. The ECtHR stated that the procedure on the judicial review of a tax fine decision can be interpreted as a 'criminal charge', because the nature of the procedure and the severity of the punishment, thus it met with the Engel criteria. Therefore, the Hungarian petty offences are obviously under the scope of article 
6 (1) of the ECHR (Rozsnyai 2019: 108 and Nagy, 2000: 196-198). The presence and the trial should have an important role in these proceedings.

The dual nature of the petty offences law is mirrored by the Hungarian regulation on the proceedings of them. Although the transformation of the regulation has transformed during the last decades and the criminal nature of the petty offences has been strengthened, and the guarantees of the proceedings became more significant, there are several regulation on the simplification and on the speed up of these proceedings (Király, 2013: 125-132). The administrative nature of the proceeding is a dominant one in minor cases. The decisions are mainly made without hearing, the decision-making bodies are administrative authorities and not courts, and there are ample opportunities for immediate actions: spot fines can be applied broadly in these cases (Bisztricki \& Kántás, 2017: 360392). The criminal nature of the proceedings is mirrored by the procedural rules of the major cases. Those cases can be interpreted by major petty offences cases in which custodial arrest can be applied by the courts. Because of the possibility of the custodial sentence the decisions are made by the courts, as a guarantee. However, there are some regulation of speeding up the procedures, a hearing must be held as a principle Király, 2013: 231-237).

\section{$4 \quad$ Being present in petty offences (?)}

The presence of the defendant in the petty offence proceeding is a principle in these proceedings, but the general rule prevails only to a limited extent. The main reason of it that majority of the petty offences cases belongs to the minor petty offences. The procedure on minor cases has merely an administrative nature. Majority of petty offences cases were traffic offenses (in 2018 76,91\% of the petty offences were traffic offenses according to the Hungarian Criminal Statistics System). ${ }^{1}$ These minor cases can be decided by the administrative authorities. Till 2019 the decision in minor petty offence cases belonged primarily to the competences of the district offices of the County Government Offices and the police authorities. The system was unified from $1^{\text {st }}$ January 2020 , now the police authorities are the primary petty offence authorities. Therefore similarly to other Eastern Central European countries (like Poland) (Czurik - Kostrubiec, 2019: 34-35) - the administrative nature of these procedures has been dominant. This administrative nature of the petty offences can be observed in the sanctions, as well. Vast majority of the petty offence punishments were spot fines which has been decided directly by the police and administrative authorities. 
I. Hoffman: Being Present in the Administrative Criminal Law: Regulation on Presence of the Hungarian Petty Offence Procedure

Table 1: Punishments in petty offences cases $2014-2018$

\begin{tabular}{|l|r|r|r|r|r|}
\hline Punishments & $\mathbf{2 0 1 4}$ & $\mathbf{2 0 1 5}$ & $\mathbf{2 0 1 6}$ & $\mathbf{2 0 1 7}$ & $\mathbf{2 0 1 8}$ \\
\hline Confiscations & 666 & 452 & 560 & 3542 & 4919 \\
\hline Custodial Arrests & 28740 & 5485 & 2103 & 1670 & 744 \\
\hline Admonitions & 57087 & 51486 & 50223 & 49222 & 52511 \\
\hline $\begin{array}{l}\text { Suspended custodial } \\
\text { arrests }\end{array}$ & - & - & 3 & 35 & 11 \\
\hline Spot fines & 667320 & 548774 & 560516 & 538806 & 494104 \\
\hline Driving bans & 10266 & 11348 & 13967 & 15252 & 16556 \\
\hline $\begin{array}{l}\text { Prohibitions from } \\
\text { staying in a particular } \\
\text { area }\end{array}$ & 6 & 9 & 7 & 7 & 4 \\
\hline $\begin{array}{l}\text { Community service } \\
\text { works }\end{array}$ & 2514 & 1925 & 1807 & 1472 & 706 \\
\hline Fines & 148143 & 124177 & 130908 & 127925 & 134302 \\
\hline
\end{tabular}

Source: BSR - (https://bsr.bm.hu/Document, downloaded at November $5^{\text {th }} 2019$

In the last five years spot fines have been the dominant form of punishments and even in $201870,58 \%$ of the them were spot fines (see Figure 1 and Figure 2). The share of the fines and spot fines were $89,28 \%$ of the petty offence punishments in 2018 . 
Figure 1: Punishments in petty offences cases 2014-2018

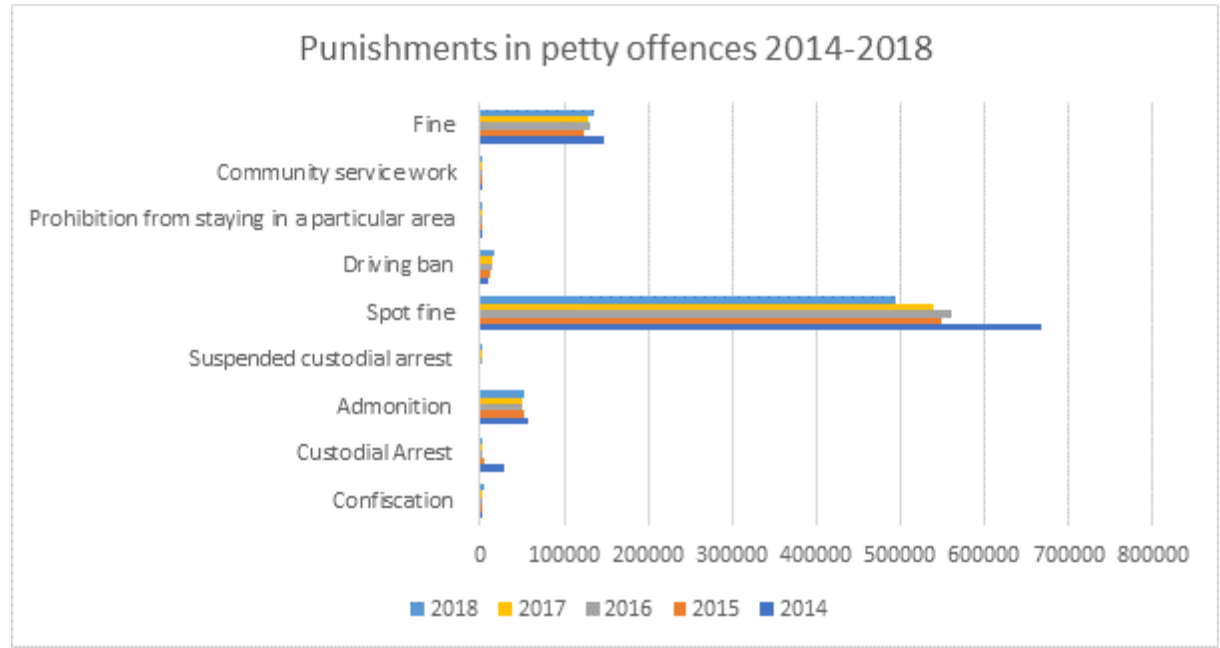

Source: BSR (https://bsr.bm.hu/Document, downloaded at November $5^{\text {th }} 2019$ ).

Figure 2: Punishments in petty offences in 2018 (in \% of the punishments)

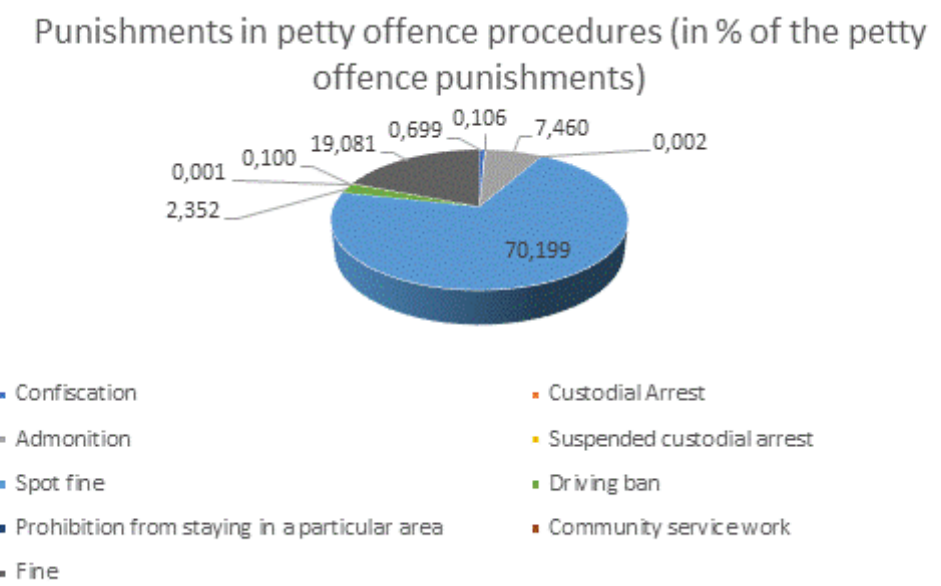

Source: BSR (https://bsr.bm.hu/Document, downloaded at November $5^{\text {th }} 2019$ ).

According to the European traditions and to the legislation in the field of fundamental rights - especially the requirements of the ECHR (interpreted by the ECtHR) - the presence is obligatory at the court procedures. The Hungarian regulation meets these requirements, because the possibility of the presence of the defendant is guaranteed in 
I. Hoffman: Being Present in the Administrative Criminal Law: Regulation on Presence of the Hungarian Petty Offence Procedure

petty offence cases, especially in the court procedures. First of all it should be emphasised that - as I have mentioned earlier - the court cases are just the minority of the petty offence cases: in 2018 6,91\% of the petty offence cases belonged to the competences of the courts - see Figure 3).

Figure 3: Petty offence competences (2014-2018)

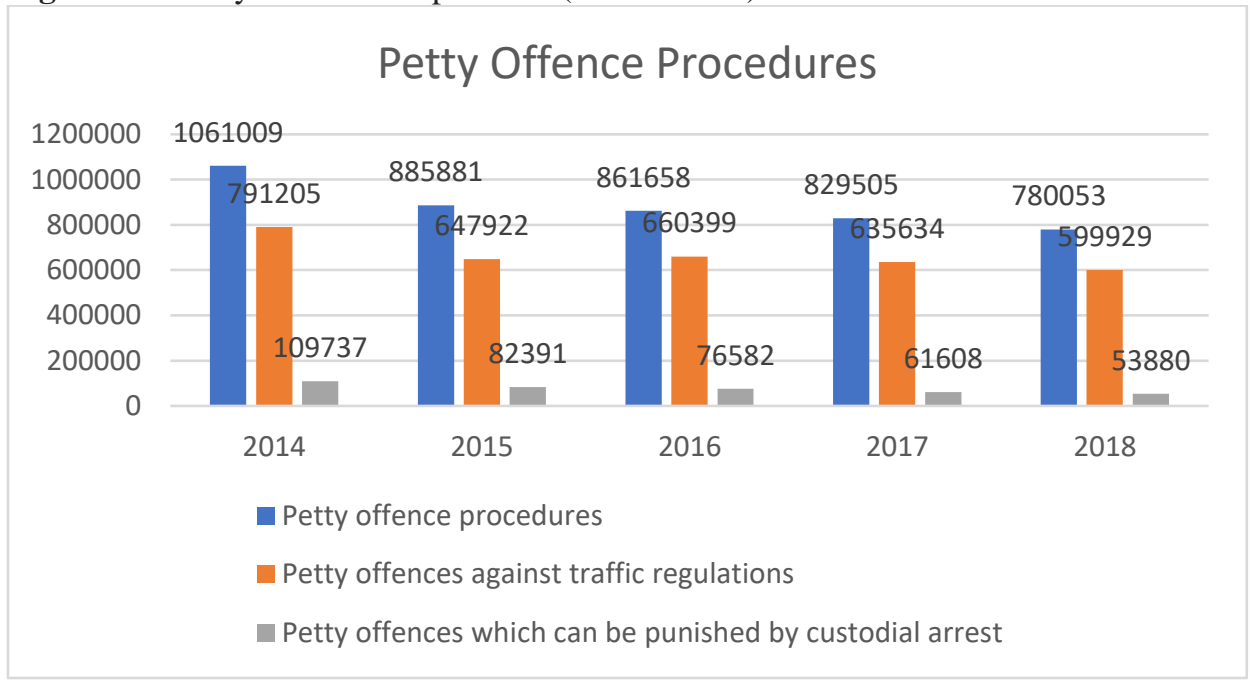

Source: BSR (https://bsr.bm.hu/Document, downloaded at November $5^{\text {th }} 2019$ ).

The presence of the defendant in court cases is a principle, but there are several cases for example if the facts are clear and the hearing of the defendant(s), witnesses, victims and experts (expert witnesses) are not necessary - when the hearing is not required (Király, 2013: 198-202). If the petty offence decisions have been made by administrative authorities and the court procedure can be interpreted as a remedy, the trial and hearing is not required, but it is available upon request (Nagy, 2013: 330-335). Therefore, the presence is often not automatic, it should be requested. This is the reason, that the notifications on the procedural acts are important. These notifications are done mainly by postal services, but there is a possibility of electronic communication. The notification deadlines are very strict. If they are missed, the presence can be guaranteed hardly.

The importance of presence of subjects of the procedures are decreasing in Hungary. The number of the petty offence cases are constantly decreasing. The main reason of the is mainly the 'administratisation' of these infringements. Although the criminal nature of the petty offences has been strengthened since 1999, new forms of administrative liability have evolved in the first decade of the 2000-s. The new form of 'administrative fine' became the major form of the sanctions for traffic infringements. This fine is a purely administrative one: not only the procedure is an administrative procedure - regulated by 
the General Code of Administrative Procedures, the CACP (Act CL of 2016) - but the liability in these cases is an objective one. The administrative fine shall be paid not by the offenders, but by the vehicle operator. The number of administrative fine cases has been increased significantly. Because o the great role of the traffic petty offenses, the decrease of the number of petty offences cases has been resulted by the growth of the administrative cases (see Figure 4).

Figure 4: Petty offences and administrative fines (2015-2018)

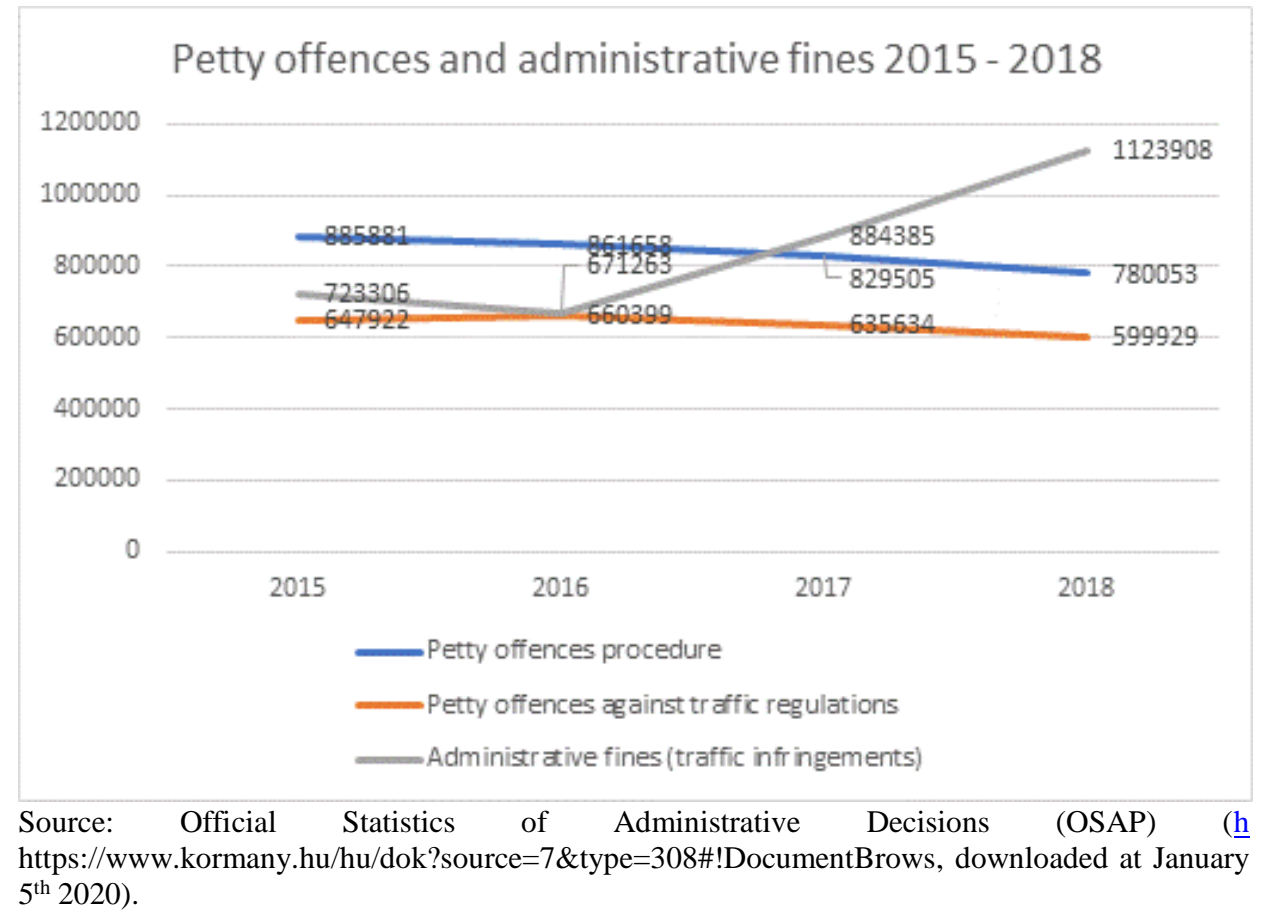

\section{$5 \quad$ Is it obligatory? - The petty offence procedures and the Directive 343/2016/EU}

The criminal nature - and thus the procedural guarantees - have been strengthened by the petty offence reforms, but the significance of them has decreased in the last years. As I have mentioned, these cases are interpreted by the ECtHR as 'criminal', as well. The Directive 343/2016/EU was adopted in 2016 to harmonise the different regulations on presumption of innocence and of the right to be present at the trial in criminal proceedings. 
During the legislation procedure of the directive, the scope of it was a great question of debates. As I have mentioned earlier, the concept of 'criminal charges' - thus the concept of 'criminal case' - is interpreted broadly by the ECtHR. The EU has not accessed to the ECHR, but its Member States are part of that all-European regime (Gragl, 2013: 89). There were strong arguments for the application of the broad interpretation on 'criminal cases' of the ECtHR in the European Union law (Satzger \& Zimmermann, 2019: 635). Despite this background, a narrow interpretation has been applied by the Directive. The paragraph (11) of the preamble states, that the dual nature cases - which includes the petty offences in the majority of the Member States of the European Union - are not covered by this Directive. ${ }^{2}$

Thus, the Directive should not apply to the petty offence procedures in Hungary because of the dual - and partly administrative - nature of the Hungarian petty offences. Therefore, the harmonisation of the Hungarian petty offence regulation cannot be examined by the European Court of Justice. But if we look at the Hungarian national rules, it can be stated, that the guarantees of the Directive are prevailed by the national legislation. The reason of this regulation is the broad interpretation of the article 6 of the ECHR by the ECtHR. Therefore, the Hungarian rules on the petty offence proceedings should not be harmonised by the Directive, but it should be consistent with the ECHR. Therefore, it would not be a great change for the Hungarian legislation if the Directive should be applied for the dual nature cases, as well.

\section{Conclusions}

The petty offences in the majority of the European - continental - legal systems have a dual nature: they have criminal and administrative elements. Therefore, they can be interpreted as 'administrative criminal law' (Köhler, 1997: 82). This continental especially German - concept - Verwaltungsstrafrecht - of administrative criminal law (Binder \& Trauner, 2014: 214-215) is applied by the Hungarian national legislation, as well.

Although the Directive 343/2016/EU is not based on the broad interpretation of criminal cases of the practice of ECtHR, and the Directive shall not be applied in Hungarian petty offence proceedings, the main guarantees of the Directive are prevailed by the major petty offence cases. If the procedures can result a detention nature punishment (in Hungary: elzárás - custodial arrest) the guarantees of the presence of the defendants mainly prevails. In more administrative - thus minor - cases in Hungary simplified and administrative nature procedural rules are applied. 


\section{Notes:}

${ }^{1}$ The source of the statistical data is the Bünügyi Statisztikai Rendszer (BSR) (Criminal Statistics System), which is available on the website: https://bsr.bm.hu/Document.

${ }^{2}$ See par. (11) of the preamble of the Directive 343/2016/EU: ,This Directive should apply only to criminal proceedings as interpreted by the Court of Justice of the European Union (Court of Justice), without prejudice to the case-law of the European Court of Human Rights. This Directive should not apply to civil proceedings or to administrative proceedings, including where the latter can lead to sanctions, such as proceedings relating to competition, trade, financial services, road traffic, tax or tax surcharges, and investigations by administrative authorities in relation to such proceedings."

\section{References:}

Bisztriczki, L. \& Kántás, P. (2017) A szabálysértési jog magyarázata. Kommentár gyakorlati példákkal. (Budapest: HVG-Orac)

Czurik, M. \& Kostrubiec, J. (2019) The legal status of local self-government in the field of public security. Acta Universitatis Wratislaviensis. Studia nad Autorytaryzmem I Totalitaryzmem 41 (1), pp. 33-47.

Gragl, P. (2013): The Accession of the European Union to the European Convention on Human Rights (Oxford \& Portland, OR: Hart Publishing)

Kis, N. (2018) Az állami jogérvényesités és a közigazgatási büntetés dilemmái. (Budapest: Dialóg Campus)

Király, E. (2013) Szabálysértési jog. (Budapest: Novissima)

Köhler, M. (1997) Strafrecht. Allgemeiner Teil. (Berlin \& Heidelberg: Springer)

Kühn, Z. (2019) Comparative Law in Central and Eastern Europe, In: Reimann, M. \& Zimmermann, R. (eds.) The Oxford Handbook of Comparative Law. (Oxford: Oxford University Press), pp. 181-200.

Nagy, M. (2000): A közigazgatási jogi szankciórendszer (Budapest: Osiris)

Nagy, M. (2013): Szabálysértési jog. In: Fazekas, M. (ed.): Közigazgatási jog. Általános rész III. (Budapest: ELTE Eötvös) pp. 295-341.

Nagy, M. (2012) Quo vadis Domine? Elmélkedések a szabálysértés helyéről a 2012. évi szabálysértési törvény kapcsán, Jogtudományi Közlöny 67 (5) pp. 217-226.

Mezey, B. (eds.) (1996) Magyar jogtörténet (Budapest: Osiris)

Rozsnyai, K. (2019) A közigazgatási perjog néhány alapelvi aspektusa. Acta Humana 5 (1) pp. 107122.

Satzger, H. \& Zimmermann, F. (2019) Challenges of Trial Procedure Reform: Is European Union Legislation Part of Solution or Part of the Problem? In: Brown, D. K., Turner, J. I. \& Weisser, B. (eds.) The Oxford Handbook pf Criminal Process (Oxford: Oxford University Press) pp. 633-654.

Szatmári, L. (1961): A bírság a magyar államigazgatásban. Kandidátusi disszertáció (Budapest: MTA)

White, R. \& Ovey C. (2010): Jacobs, White, and Ovey The European Convention on Human Rights. Fifth edition. (Oxford: Oxford University Press) 